\title{
SALT NO LONGER TRAVELS THROUGH THE BOHEMIAN FOREST ALONG THE GOLDEN TRAIL, BUT HALOPHYTIC NEOPHYTES DO
}

\author{
ZDENKA K ǨENOVÁ1,2,*, ZDEŇKA CHOCHOLOUŠKOVÁ 3 , \\ and VLADIMÍR ZÝVAL ${ }^{4}$ \\ 1 Global Change Research Institute AS CR, Bělidla 4a, CZ-60200 Brno, Czech Republic \\ ${ }^{2}$ Institute for Environmental Studies, Charles University, Benátská 2, CZ-12900 Prague, Czech Republic \\ ${ }^{3}$ National Pedagogical Institute of the Czech Republic, Čermákova 18, CZ-30100 Plzeň, Czech Republic \\ ${ }^{4}$ Geo Vision s.r.o., Brojova 2113/16, CZ-326 00 Plzeň 2 - Slovany, Czech Republic \\ *Corresponding author: krenova.z@czechglobe.cz
}

\section{ABSTRACT}

\begin{abstract}
The Golden Trail, used for the transport of salt from alpine mines to the Czech Kingdom for centuries, was a crucial ancient trade route in the Central European region. The contemporary road I/4, copying the Golden Trail, plays the same role today. The l/4 is used year round with deicing salt, a common standard, applied for winter maintenance. Deicing salt is often used, even in sections where the l/4 passes through the Bohemian Forest and its protected areas. The effects of applying deicing salts on ecosystems in the region is well documented. In addition to many other effects, high concentrations of salt along the roads cause significant changes in plant communities. Plant species sensitive to salinity disappear and the abundance of halophytes increases. Roads are also trajectories for the migration of neophytes. Seeds or other propagules are transported with cargo or in car tires.

In this paper, we present our findings on the pilgrimage of Plantago coronopus, a true halophyte, into the Bohemian Forest. We also describe the species' colonisation strategy and human measures supporting its successful migration in a region of high conservation value.
\end{abstract}

Keywords: Bohemian forest; deicing salt; management of protected areas; National Park; neophytes; Plantago coronopus

\section{Introduction}

Trade trails have passed throughout Europe since ancient times, ensuring the exchange of many regional commodities. These routes have traversed densely populated landscapes and crossed mountain ridges or other hard to reach areas. The Golden Trail, used for bringing salt from alpine mines to the Czech Kingdom for centuries, was one of the most important historical trade trails in this region (Kubů and Zavřel 2007, 2015). Caravans of mules and horses crossing vast forested areas of the Bohemian Forest sought the most feasible routes and several branches of the Golden Trail gradually emerged. Today, modern roads copy some branches of the Golden Trail and the international road I/4 Prague-Passau (hereinafter $\mathrm{I} / 4$ throughout), marked B12 in Bavaria, is one of the most important in the area. Of course, transported commodities have changed, as well as modes of transport. Fast trucks and cars replaced slowly traveling horses and mules. 21st century populations require a different quality of trails (i.e. roads) and hence their requisite maintenance, too. Roads must have year round accessibility and we understand for their winter maintenance deicing salt is a common standard.

We should not forget that the effects of applying deicing salts on ecosystems are well known and documented in both urban and natural areas in many countries (Findlay and Kelly 2011). In cold regions, deicing salts applied to roads are a major contributor to local and regional contamination of terrestrial ecosystems, while salts from water softeners and septic systems are less important. In addition to the many other effects on ecosystems, high concentrations of salt also cause significant changes in plant communities (i.e. Angold 1997; Wrobel et al. 2006). More sensitive species can disappear and result in gaps in vegetation cover. The abundance of halophytes and facultative halophytes (i.e. subhalophytes), which produce many seeds and invade neighbouring plant communities, may also increase. Facultative halophytes can tolerate salty soils, but they are not more advantageous for them. Obligate halophytes, however, not only tolerate salinity, but their growth can be stimulated by $\mathrm{NaCl}$ (Flowers et al. 1977) and they are good indicators of salinity.

Because of the well-known negative effects of applying deicing salt in many countries, their application to roads in protected areas is prohibited by law in the Czech Republic. There are special exceptions for several of the central arteries in the Šumava National Park (Šumava NP) and Šumava Protected Landscape Area (Šumava PLA) though, and deicing salts are applied when particular conditions prevail. The first monitoring of the effects of deicing salt on ecosystems in the Šumava NP was done in the 1990's and routine monitoring began in 2003. Recently, phytoindication monitoring is conducted and soil samples for chemical analysis are collected annually (Zýval et al. 2015).

Dataloggers recording water level, temperature and conductivity are used for monitoring the impact of deicing salt on water ecosystems in the Šumava NP since 2016 (Zýval et al. 2018). There was little detailed information on the effects of these salts on ecosystems in the Bavarian Forest NP, since the first preliminary study was 
only carried out in 2011 and 2012 (Křenová et al. 2012). This study, as well as repeated monitoring conducted in 2015 and 2018 showed that ecosystems along the main road running through the old part of the Bavarian Forest $\mathrm{NP}$, the "Nationalparkstrasse" were significantly affected by deicing salts (Kř̀enová et al. 2018). Vegetation analyses revealed significant differences in the occurrence of halophytes and sub-halophytes among studied sites with increasing numbers of halophytes and sub-halophytes recorded at sites along this main road, particularly between Altschönau and Spiegelau. We have recorded more than thirty halophytic and subhalophytic species that were previously known from the Czech side of the Bohemian Forest (Zýval et al. 2015). As early as 2012, we also found Plantago coronopus, a new species that had not been mentioned before in this area. We began looking for this species in the Bohemian Forest and a central question was whether this species also occurred in adjoining Czech regions.

In this paper, we report the pilgrimage of the Buck'shorn plantain in the Bohemian Forest, from Bavaria to Czechia. We also elucidate the species' colonisation strategy and human measures supporting its successful migration.

\section{Methods}

\section{Study area}

The Bohemian Forest is one of the largest forested landscape in Central Europe and covers the highest ridges of the low mountain range that forms the watershed between the Danube and Elbe catchment areas. Two national parks, the Bavarian Forest National Park (Bavarian Forest NP, Germany) and the Šumava National Park (ك̌umava NP, Czech Republic) were established in the Bohemian Forest in 1970 and 1991, respectively, and protect the area with the highest conservation value (Křenová and Kindlmann 2015, 2018). Two national parks together with the Bavarian Forest Nature Park (300,800 ha, established 1967) and the Šumava Protected Landscape Area (99,624 ha, established 1963) create the great Bohemian Forest ecosystem. The latter two can be understood as buffer zones of the two national parks (Fig. 1).

The greater area is a unique mosaic of natural and secondary habitats of exceptional natural value with European-wide significance. Each type of habitat hosts numerous rare and protected plant and animal species. Forests cover over $80 \%$ of the Sumava NP, the largest national park in the Czech Republic $(68,064 \mathrm{ha})$, and peat bogs and natural wetlands are the second most important habitat in this area. The Bavarian Forest NP $(24,235 \mathrm{ha})$ is approximately $98 \%$ covered by forest (Elling et al. 1987) and peat bogs are again its second most important habitat in this area. The region is characterized by montane and high montane areas within a vertical range of roughly $800 \mathrm{~m}$ (from 650 to $1,420 \mathrm{~m}$ a.s.l.). The soils are nutrition poor with cambisols, cryptopodzols, podzols, and organic soils being the most common (Kočárek 2003). At all altitudes, but especially in the valleys, there is characteristically a persistent or intermittent water-table in both mineral and organic soils (Bässler et al. 2009).

At a larger scale, the Bohemian Forest is in the temperate zone and subject to both Atlantic and continental

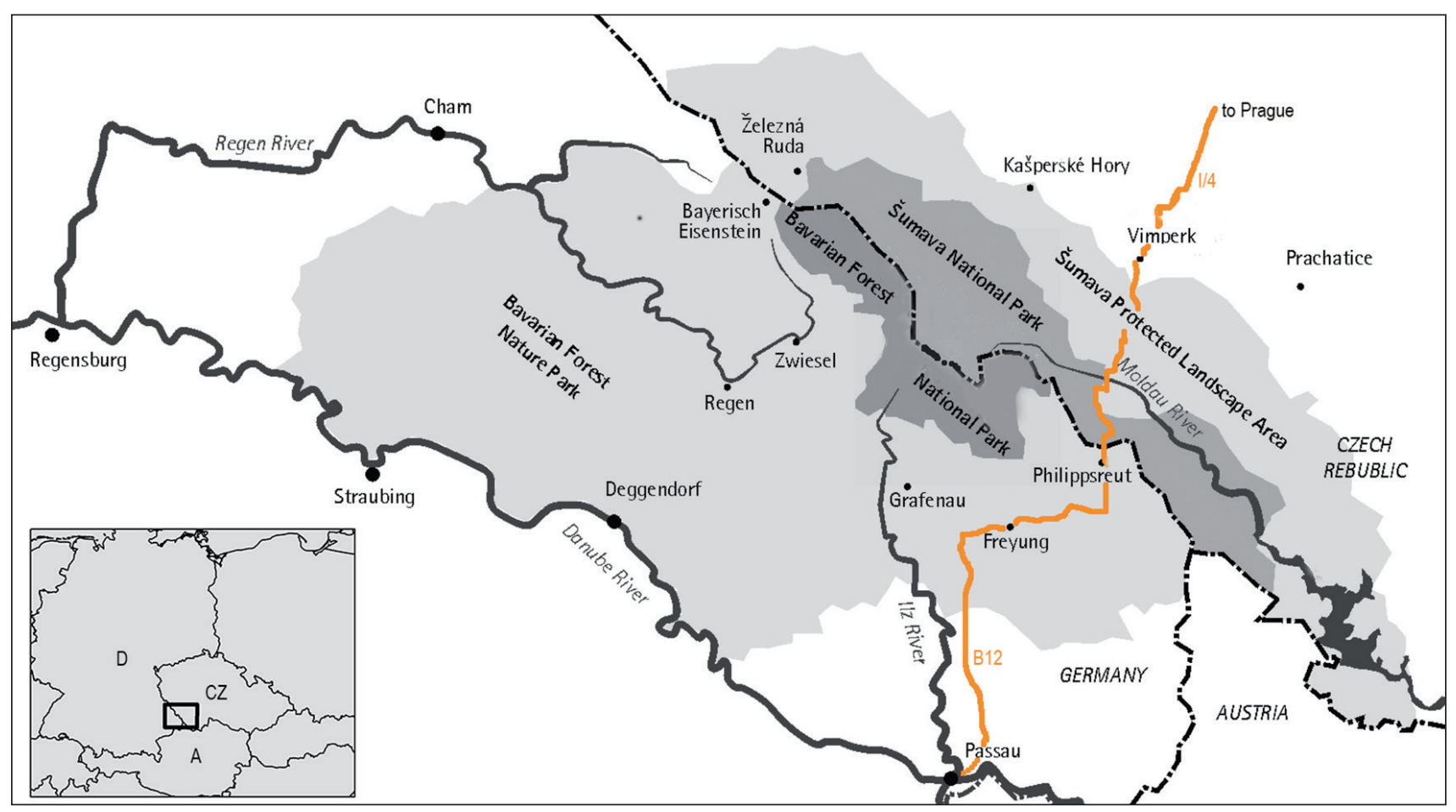

Fig. 1 Great Bohemian Forest ecosystem. Four large protected areas and the main international road Prague - Passau (marked l/4 in CZ and B12 in Germany) are shown. 
influences. The cold mountain climate of the region is characterised by an average annual temperature of $4.2{ }^{\circ} \mathrm{C}$ and average rainfall of 1,090 $\mathrm{mm}$ (Czech Hydrometeorological Institute - Churáňov station, 1,118 m a.s.l.; http:// www.chmi.cz/). The total annual precipitation on the Bavarian site is between 1,200 and 1,800 mm depending on altitude. Annual mean air temperature ranges from $5.1^{\circ} \mathrm{C}$ in the valleys, $5.8{ }^{\circ} \mathrm{C}$ on hillsides and $3.8^{\circ} \mathrm{C}$ in the high montane zones (Noack 1979; Bässler 2004). Snow cover differs from year to year. In Bavaria, continuous snow cover over the last ten years has averaged about twenty weeks with an average snow depth of $45.7 \mathrm{~cm}$. Several days per year with more than $100 \mathrm{~cm}$ of snow cover are also common in this area (data from the Bavarian Forest NP Authority). The richest in snow are the positions at the highest altitudes around the state border. Continuous snow cover occurs on average during 90 to 100 days a year in the lowest positions and in more than 200 days in the highest positions of the Bohemian Forest. The first day with snow cover in the lowest positions is at the end of October, in the highest positions at the beginning of the month (exceptionally also in September). The last day with snow cover in the lowest altitudes is at the end of April, with the highest positions in mid-May, however there is still a discontinuous snow cover until the end of May and exceptionally until mid-June. Snow cover acquires the greatest mass in lower positions in February, in the peaks of Šumava in March. The average maximum height of snow cover ranges from $40 \mathrm{~cm}$ in the lowest positions to $150 \mathrm{~cm}$ and more in the highest (data from the Šumava NP Authority).

\section{Study species}

Plantago coronopus (L.), Buck's-horn plantain, is a wind-pollinated, self-compatible annual or short-lived perennial herb that mainly occurs in southern Europe and North Africa. It also occurs in north-western Europe along the Atlantic and North Sea coast and all the way to south-east Asia (Fig. 2; Hultén and Fries 1986; Villellas et al. 2013). Records of this species from inland sites refer to secondary habitats, usually of anthropic origin.

P. coronopus is a true halophyte (Flowers et al. 1977). The species remains viable and completes its life cycle at seawater salinity; however, its germination decreases with increasing concentration of $\mathrm{NaCl}$, i.e. a facultative halophyte (Bueno et al. 2017). Ellenberg (1991)

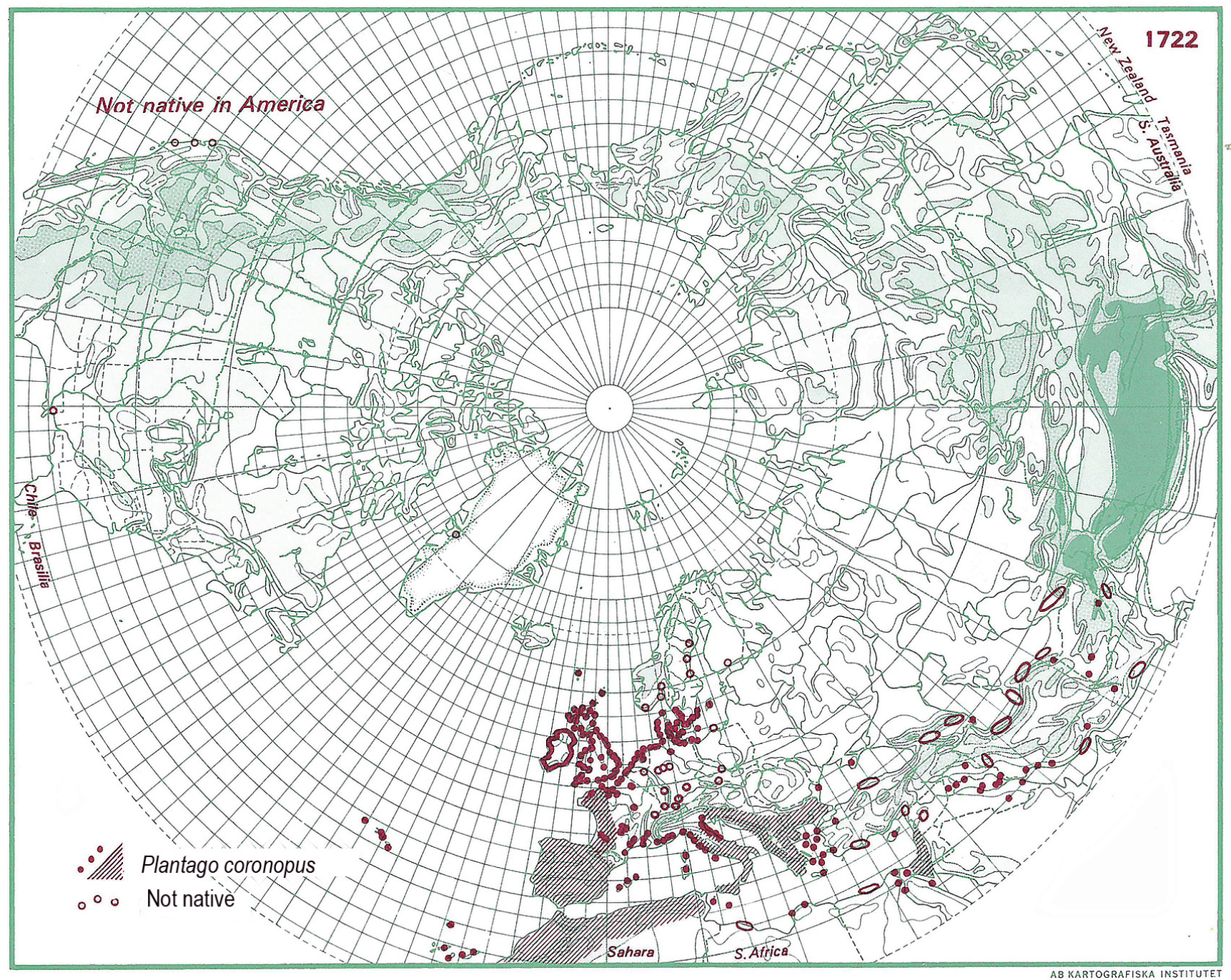

Fig. 2 Natural range of Plantago coronopus (adapted from Hultén and Fries 1986). 
classifies $P$. coronopus as a mesohalophytic species usually colonizing soils with a low to a moderate chloride content $\left(0.5-0.7 \% \mathrm{Cl}^{-}\right)$. It is a drought-tolerant and drought-adapted plant species (http://www.sussex .ac.uk/affiliates/halophytes/). It grows in sandy or gravelly soils and cracks in rocks, in sunny places in dry soils usually near the sea (Clapham et al. 1962). It is one of the first colonizers of bare sand flats in the Netherlands (Koelewijn 2004). It is edible and occasionally grown and used in herb salad and as a garnish. This plant is commonly harvested and eaten in the Maritimes and it is currently a popular frost-hardy winter crop for farmers in northern climates where it is usually grown in unheated tunnels (Baldwin et al. 2012).

Individuals contain one or several basal rosettes from which flowering stalks can emerge with an inflorescence. Each leaf axil has an axillary meristem that can produce either a spike or a lateral rosette, or remain dormant.

It is a gynodioecious and predominantly outcrossing species. P. coronopus hermaphroditic flowers are protogynous, the stigma emerges first, and after approximately 3-4 days the anthers appear (Koelewijn and van Damme 1995). Flowering and subsequent maturation occur from the base of the ear upwards (Koelewijn and van Damme 2005). This species flowers from the beginning of May through to September and can overwinter as a rosette.

The species physiology (Koyro 2006), reproduction (Dinnétz and Jerling 1997), germination (Waite and Hutchings 1978), demography (Waite 1984) and ecological characteristics (Smekens and Tienderen 2001; Koelewijn 2004) have been previously studied. However, all these studies were done with samples from native populations growing in the coast or inland salt marshlands. Ecology of this species growing in secondary habitats, i.e. along roads treated by deicing salt, have not been studied previously.

\section{Search methods of the species occurrence}

We began with a literature survey and analysis of floristic databases in Germany, Austria and Czech Republic to learn more about the historical distribution of the Buck's-horn plantain (Plantago coronopus) in Central Europe.

We have searched for P. coronopus in the Bohemian Forest region since 2012. We started with permanent study sites, which were established in the Bavarian Forest NP in 2011 (Křenová et al. 2012). In addition to those sites, sixty-five transects $(200$ meters long and $60 \mathrm{~cm}$ wide) were established along the central segment of the Nationalparkstrasse (730-830 m a.s.l.) in order to quantify a proportion of the area along the road affected by deicing salt. All vascular and bryophytes as well as their abundances (Braun-Blanquet 1951, 5 degrees scale) were recorded along all these transects. Monitoring of these 65 transects first took place in 2012 and repeated in 2015 and 2018. Data about abundances of P. coronopus were used for this study.
After the first record of the Buck's-horn plantain (P. coronopus), we also searched for the species in other parts of the Bohemian Forest region. Since 2012, we have walked all the roads treated by deicing salt in the region and searched for the species. GPS coordinates of newly found individuals or small colonies were recorded. We primarily focused on the roads in protected areas, i.e. in Bavarian Forest NP and in Šumava NP and Šumava LPA, where applying of deicing salt is regulated. We also searched along the central roads outside protected areas. The I/4, international road Prague - Passau, the most trafficked in the region, was the centre of our interest.

Newly, 16 transects of the same design (200 meters long and $60 \mathrm{~cm}$ wide) were set in 2015 with the aim of monitoring the Buck's plantain occurrence and its abundance along the $\mathrm{I} / 4$ from the border to inland, where the species was first recorded on the Czech side of the Bohemian Forest in 2014. The monitoring along the I/4 was repeated in 2018 and again in 2020 and 2021, after the completion of large road reconstructions in 2019.

\section{Results}

\section{Distribution and historical records in Germany and the Czech Republic}

Reviewing the literature, we found that in Germany (Fig. 3) there are records of Plantago coronopus subsp. coronopus (Rothmaler 2005) growing along the coast, in Lower Saxony and Schleswig-Holstein. This species naturally occurs in salt meadows from Mecklenburg-Vorpommern to Nordrhein-Wistfalen and Saxony-Anhalt. According to Oberdorfer (2001) this species occurs along the North Sea and Baltic coast, in Harzrandmulde - Magneburger Börde - Saxony, Lower Saxony, Fränkisches Keuper and Liasland, Haßberge and Frankenalbvorland and Oberrheinebene. Plantago coronopus is not included in the Austrian Flora (Adler et al. 1994).

Before 2016, there were few records of Plantago coronopus in the Czech Flora (Slavík 2000) and the Czech main botanical database (www.florabase.cz, Chytrý and Rafajová 2003). In the database, the first record dates from 1959, when this species was found at the industry complex Vítkovické železárny KG in Ostrava, North Moravia, 420 m a.s.l. (Kilián and Krkavec 1961). The second record is from 30 November, 1987, when Dr. Pyšek found this species on an industrial dump at the Kovosvit factory, Sezimovo Ústí, South Bohemia (Štech et al. 1988); this location was confirmed again in 2005. Both the Czech Flora (Slavík 2000) and Kubát et al. (2002) state that this species was first recorded on slag heaps at Třinec, North Moravia.

The new database of the Czech flora and vegetation (https://pladias.cz/, Chytrý et al. 2021) has more records (Fig. 4), most of them from last five years. There are several records from our region. All of them are from 2016 or younger. 


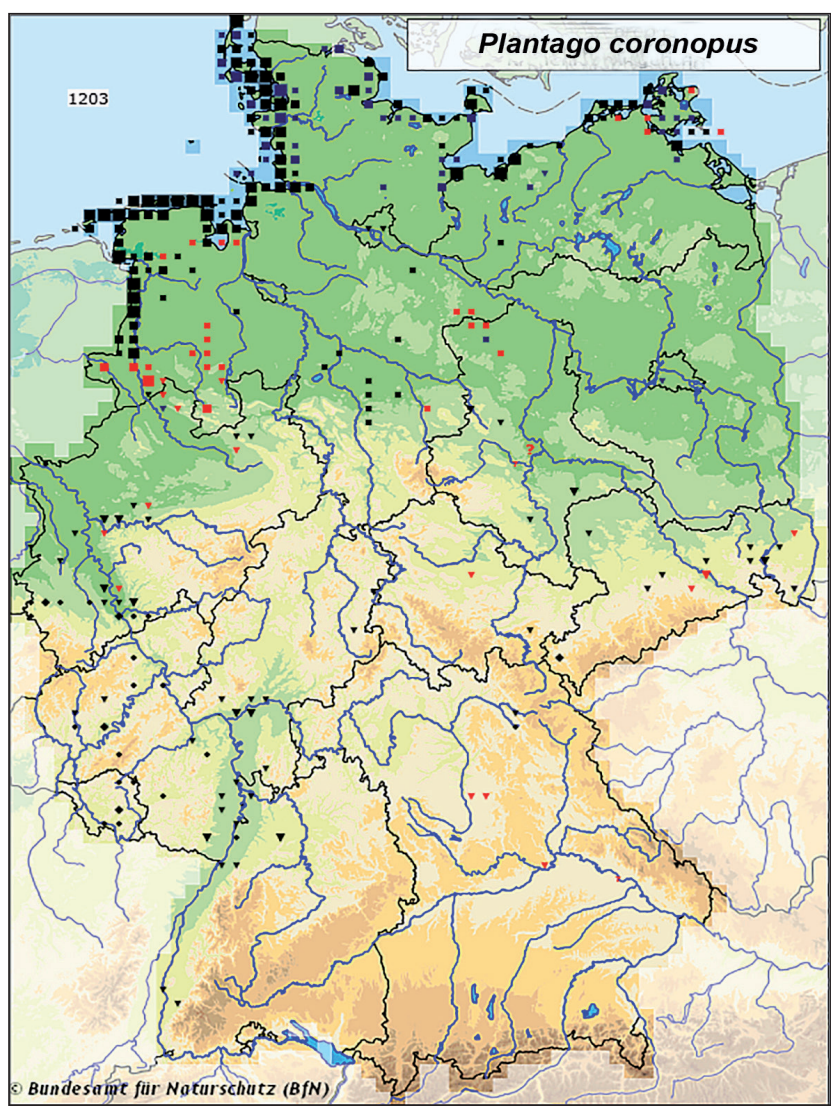

Fig. 3 Occurrence of Plantago coronopus in Germany (adapted from www.floraweb.de). Red points show data recorded before 1950, blue marks are data from 1950-1990 and black points are data since 1991 and later.
The database of the Czech Nature Conservation Agency (AOPK ČR 2021) has 18 records of $P$. coronopus from 2013-2021 (Fig. 5). Only one record is from our region. The species was recorded along the I/4 near Kortusova Hut in 2018.

\section{New species recordings in the Bohemian Forest}

In 2011, during the first year of the monitoring project, we recorded Plantago coronopus at three sites from nine we monitored along the Nationalparkstrasse in the Bavarian Forest NP (Křenová et al. 2012). Two locations were close to the Grosse Ohe River (location S4: N48 ${ }^{\circ}$ 55.416 ${ }^{\prime} \mathrm{E} 13^{\circ} 24.862^{\prime}, 765 \mathrm{~m}$ a.s.l.; location S5: N48 ${ }^{\circ} 55.406^{\prime}$ $\mathrm{E} 13^{\circ} 24.817^{\prime}, 765 \mathrm{~m}$ a.s.l.) and the last was near Altschönau (S9: N48 ${ }^{\circ} 44.664^{\prime}$ E13 $27.977^{\prime}, 748 \mathrm{~m}$ a.s.1.). The species always occurred only at the edge of the asphalt road and it was the dominant species there. No older records of this species were found from this area or other parts of the Bohemian Forest.

During the first year of our survey, we were not sure if $P$. coronopus, a species natural in moderate maritime climate, could survive at such cold locations. The temperature was less than $-20{ }^{\circ} \mathrm{C}$ on several days in February 2012 in parts of the Bavarian Forest NP; nevertheless, the occurrence of $P$. coronopus was confirmed in 2012 and again in 2015 and 2018. Since summer 2012 we have also recorded this species at two other permanent study sites Grosse Filz (S7: N48 $55.338^{\prime}$ E13 $25.210^{\prime}, 777$ m a.s.l.) and Guglöd (S8: N48 55.388' E13 ${ }^{\circ} 25.106^{\prime}, 769$ m a.s.l.).

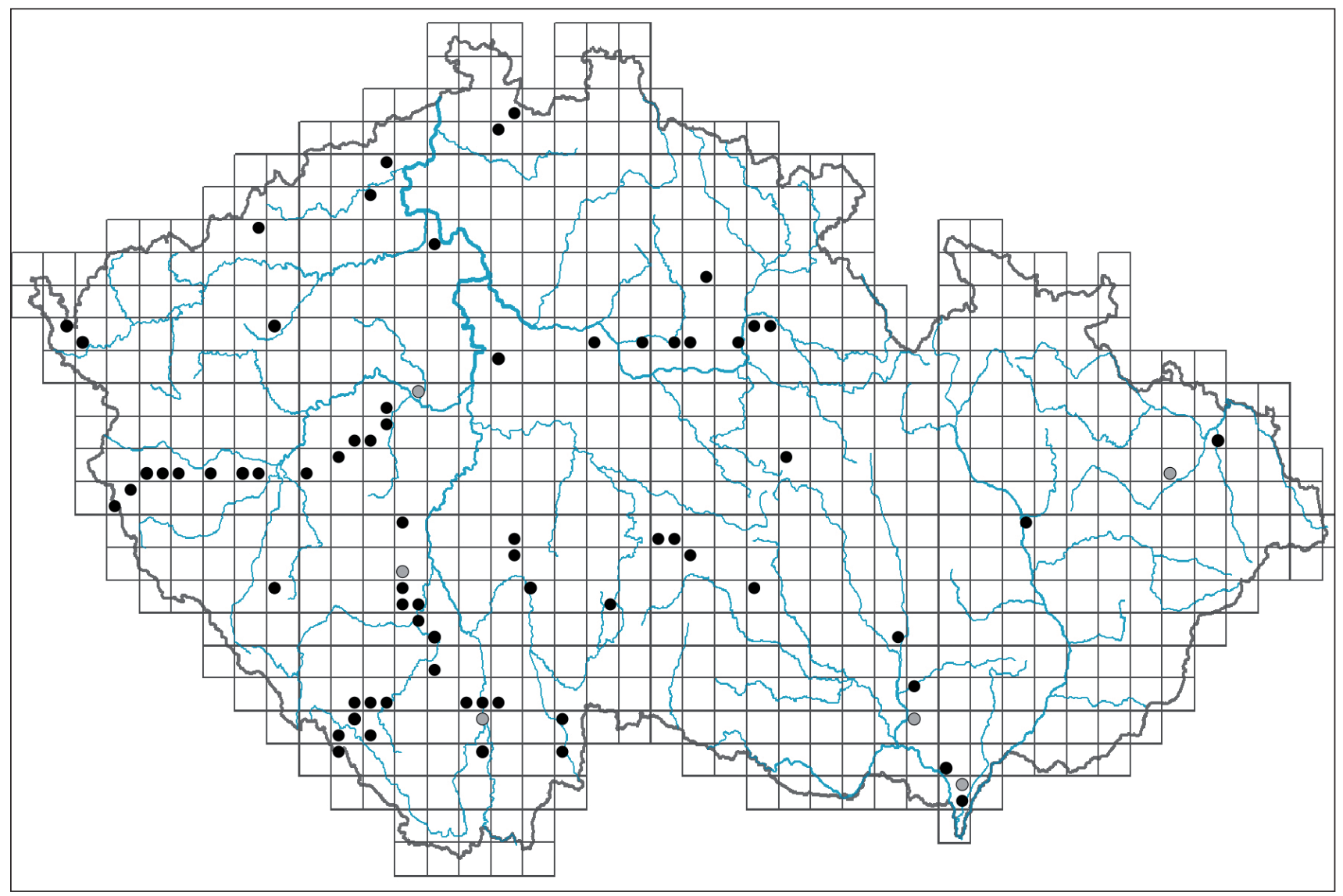

Fig. 4 Occurrence of Plantago coronopus in the Czech Republic (www.pladias.cz). 


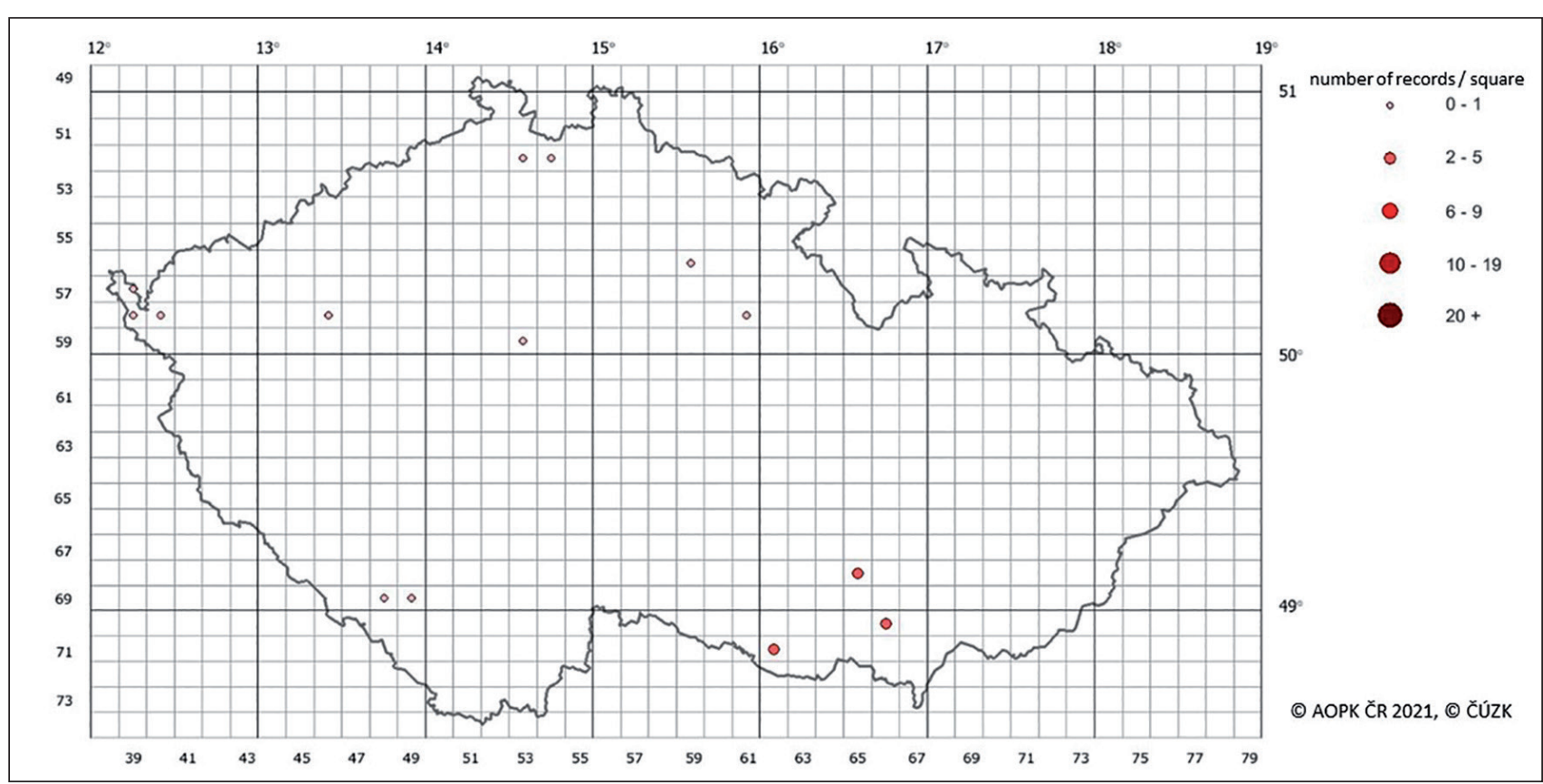

Fig. 5 Occurrence of Plantago coronopus in the Czech Republic (www.portal.nature.cz).

Chemical analysis of soil samples from these locations confirmed an increasing conductivity and concentration of $\mathrm{Na}^{+}$and $\mathrm{Cl}^{-}$ions (Křenová et al. 2018).

With the first monitoring of 200 meter long transects in Bavaria in 2012, we recorded Plantago coronopus in 33 transects (51\% of all transects) established along the main part of the Nationalparkstrasse. P. coronopus was recorded in 42 transects in 2015 and in 47 transects in 2018 , it was found in $65 \%$ and $72 \%$ of transects respectively. In all cases, $P$. coronopus plants occurred only at the edge of the asphalt road maintained by deicing salt ( $\max$ $15 \mathrm{~cm}$ from the edge of the road). Plants grew in different densities, from several individuals to hundreds of plants in some places. It was a dominant species in some transects. In the control transects, established along the parallel road not maintained by deicing road, there were

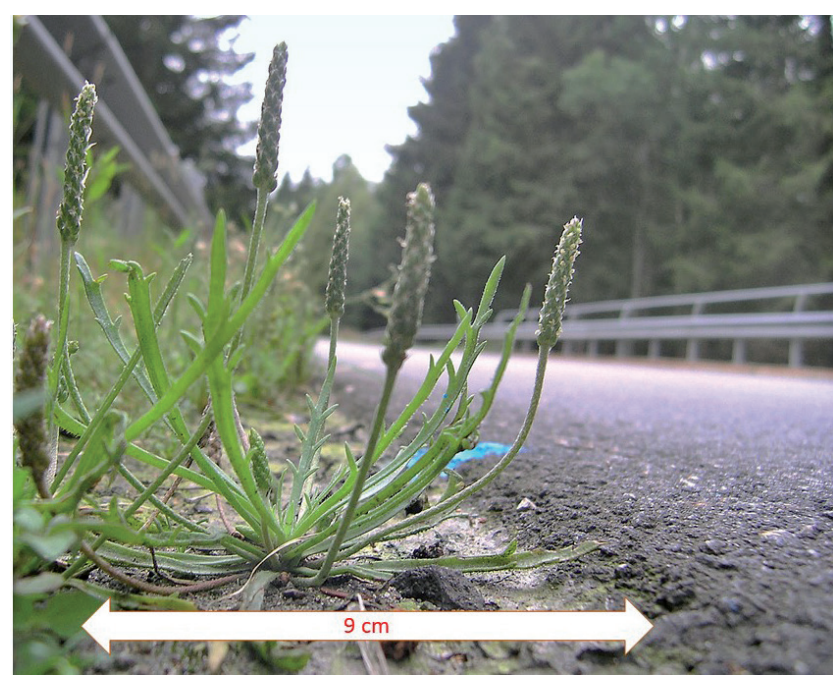

Fig. 6 Individuals of Plantago coronopus growing along the Nationaparkstrasse road are small and grow very close to the asphalt road edge. no individuals of $P$. coronopus. The morphology of these plants was the same as in 2011 and later. All plants were small, up to $10 \mathrm{~cm}$ tall with a rosette of maximum $10 \mathrm{~cm}$ in diameter. Leaves in rosettes were ascending and small. Individuals had usually only five or six stems with cobs per plant (Fig. 6).

In May 2013, we found several small plants of $P$. coronopus along the $\mathrm{I} / 4$. We checked the occurrence of this species more carefully in summer 2013. There were dozens of plants at an altitude of $950 \mathrm{~m}$ a.s.l., the highest point along the I/4, where it crosses the main ridge of the Bohemian Forest and watershed between the Danube and Vltava Rivers (N $48^{\circ} 52.411^{\prime}$, E $13^{\circ} 41.357^{\prime}$ ). Closer to the Czech border this species was less abundant and the last few individuals or small groups of Plantago coronopus were recorded $1.5 \mathrm{~km}$ from the border, on eastern edges of the road $\left(\mathrm{N} 48^{\circ} 52.411^{\prime}\right.$, E $\left.13^{\circ} 41.357^{\prime}\right)$. We carefully searched for the species along the same road in 2013 in Czechia but no individuals of the Buck's-horn plantain were found.

In summer 2014, the first small individuals of this species were recorded along the $\mathrm{I} / 4,0.5 \mathrm{~km}$ inside the Czech Republic (N 48 $53.122^{\prime}$, E 13 $\left.42.316^{\prime}\right)$. A more or less continuous $10 \mathrm{~cm}$ wide and more than $1 \mathrm{~km}$ long strip of hundreds of plants was found on the right side of the road in the direction from the Czech-German border to Strážný (N $48^{\circ} 54.106^{\prime}$, E $\left.13^{\circ} 43.221^{\prime}\right)$.

In 2015, we established fifteen 200 meter transects on the south edge of this road from the border to the Czech interior and we recorded P. coronopus in 11 transects. Usually we found only several individuals and small groups of $P$. coronopus plants in each transect. Several individuals of $P$. coronopus were also recorded along the north edge of the $\mathrm{I} / 4$, near the petrol station in Strážný (N $48^{\circ} 54.101^{\prime}$, E $\left.13^{\circ} 43.188^{\prime}\right)$. A habitus of these 
P. coronopus plants was similar to plants found in Germany. They were small, max $10 \mathrm{~cm}$ in diameter and had only few flowering stems. They grew in a narrow strip ( $\max 20 \mathrm{~cm}$ wide) along the asphalt road edge. In summer 2018, we have repeated monitoring of 11 transects on the south edge of the $\mathrm{I} / 4$ from the border to the Czech interior and we recorded $P$. coronopus in 14 transects. Abundances of plants in several transects significantly increased. More or less, there were no differences in conditions between the locations with and without Plantago coronopus occurrences. Plantains grow along the edges of the roads, often in places where there were low abundances of other plant species and that were regularly mechanically disturbed by snow plowing, mowing or sweeping. We could summarise that there are many similar locations but only some are colonized by this species. It seemed likely that occurrences of $P$. coronopus are a result of seed distribution and many new locations will be colonized in the future.

\section{Road reconstruction and surface disturbances support the spread of the species}

In summer 2018, we found four new locations of $P$. coronopus along the $\mathrm{I} / 4$ and we learned that this species profits from disturbances along road edges.

The first new location was a colony with many small plants on the Czech-German border (N 48 $52.848^{\prime}$, E $13^{\circ} 42.271^{\prime}$ ). We have already had this species occurrence records to the north and south of this site but not precisely from here. Plantains newly colonised a $1.5 \times 10 \mathrm{~m}$ plot where the grass was removed and bare soil mixed with recycled gravel in autumn 2016. P. coronopus and Puccinellia distans, another halophytic species, were the only two species creating a sparse vegetation of this new substrate. P. coronopus individuals were small ( $\max 5 \mathrm{~cm}$ in dimeter) with only one or two flowering stems (Fig. 7). Recycled gravel with a high proportion of old asphalt limited the growth of the plants. At the second, dozens of plantains were found in Kasnice (N $48^{\circ} 54.653^{\prime}$, E $13^{\circ} 45.124^{\prime}$ ), where P. coronopus plants

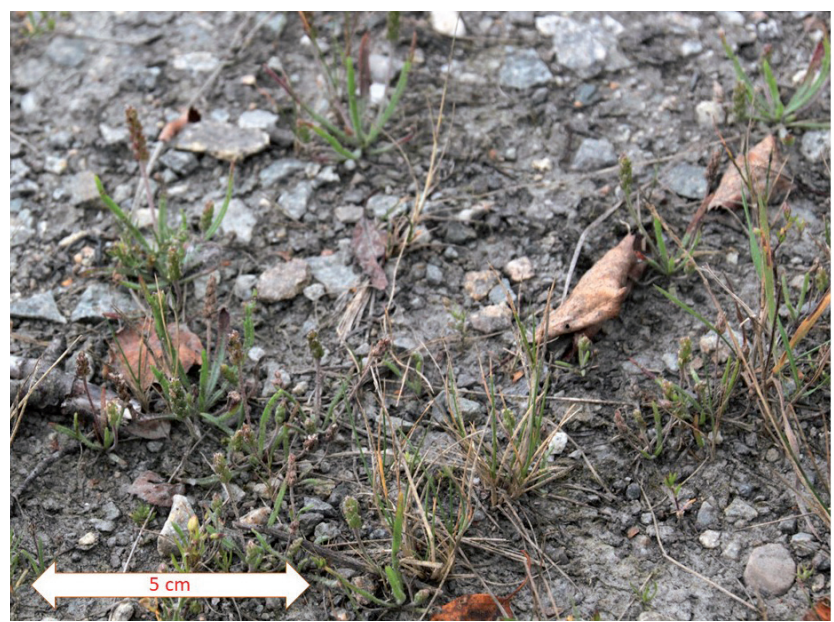

Fig. 7 Tiny plants of Plantago coronopus and Puccinellia distans created a sparse vegetation in the plot covered with recycled gravel and old crushed asphalt. used the widened edge of the road and its torn turf. This place was modified to improve the entrance to agricultural land. We found also a new population of $P$. coronopus north of Horní Vltavice (N 48 $57.7613^{\prime}$, E $13^{\circ} 45.2641^{\prime}$ ). Finally, the species was also recorded near Kortusova Hut ( $\mathrm{N} 49^{\circ} 0.49048^{\prime}$, E $\left.13^{\circ} 45.98530^{\prime}\right)$, where widening of the roadsides created a new suitable habitat for $P$. coronopus. Plantains growing in Řasnice, Horní Vltavice and Kortusova Hut were max $10 \mathrm{~cm}$ in diameter and usually had 6-8 flowering stems. These three locations were 3.5, 9.5 and $16 \mathrm{~km}$ from the nearest location where the species was recorded in 2015 . We carefully searched along the $\mathrm{I} / 4$ among all known locations, however no further P. coronopus individuals were found in 2018.

A complete reconstruction of the $\mathrm{I} / 4$ between the Czech-German border and a petrol station near Strážný was conducted in summer 2019. The old road surface was milled and a new asphalt carpet created. The edges of the roadway were changed too. Old road curbs were torn down and the road edges (about $60 \mathrm{~cm}$ wide) were covered with a new mixture of sand and gravel. Fifteen 200 meter transects established in 2015 disappeared with this reconstruction.

Nevertheless, we observed P. coronopus individuals colonizing a new substrate at the road edges in summer 2020. We restored our transects along the south edge of the I/4 and we added another 15 transects (again $200 \mathrm{~m}$ long and $60 \mathrm{~cm}$ wide) along the north edge of the road. In summer 2020, we recorded P. coronopus in seven of 15 transects on the south edge and in eight transects of 15 from the north edge of the road. We recorded only one or two plantains in several 200 meter transects. These plants were robust (more than $20 \mathrm{~cm}$ in diameter), with many leaves and often 15-25 flowering stems (Fig. 8). We did not find the remnants of the original population near these new colonists. The seeds were transported from a greater distance. In two transects, we found dozens of $P$. coronopus individuals growing in a new substrate. They likely originated from remnants of

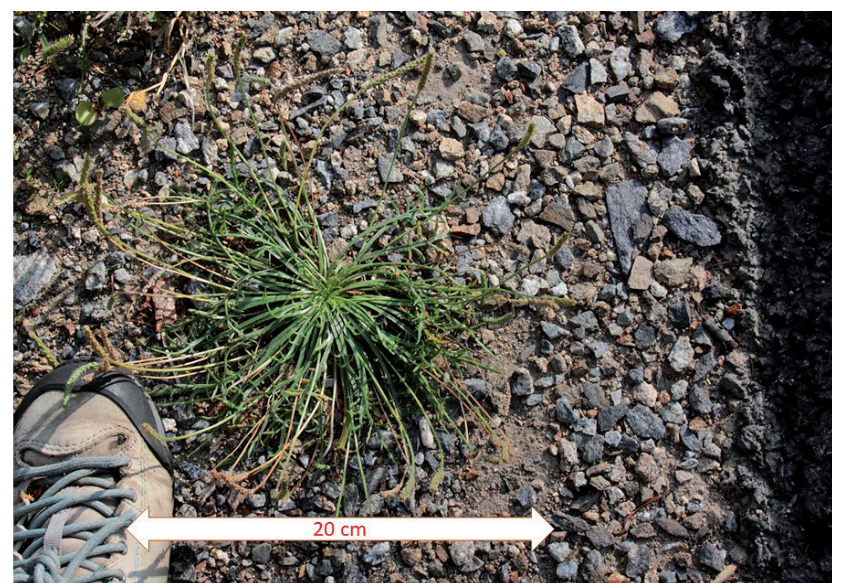

Fig. 8 Plantago coronopus individuals colonising a new substrate at the road edges were more than $20 \mathrm{~cm}$ in diameter and had many flowering stems. This species was one of the first colonists of the new road edges. 


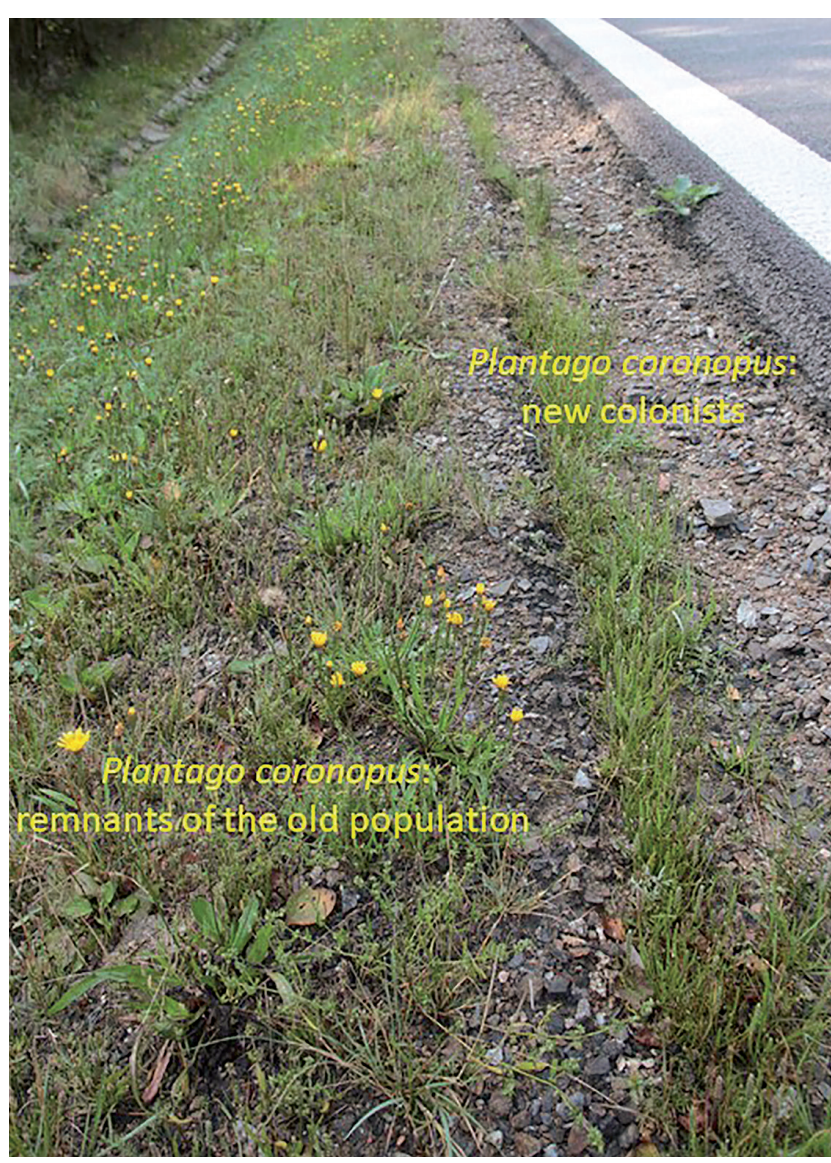

Fig. 9 Remnants of old $P$. coronopus population, which survived outside of the reconstructed road edges, produced many seeds and their offsprings successfully colonised a new substrate. Several dozens of new colonists appeared only a year after the road edge reconstruction was completed.

old populations surviving outside of the reconstructed road edge. New colonists were again more robust that $P$. coronopus individuals growing in a neighboring remnant population (Fig. 9).

In summer 2021, we repeated our monitoring and recorded P. coronopus in eight of 15 transects on the south edge of the I/4 and in nine of 15 transects on the north edge. An abundance of the species increased in several transects. In 2021, we again carefully searched for $P$. coronopus along the $\mathrm{I} / 4$ and found that migration of the species slowly continues. New individuals or smaller groups were recorded between a petrol station in Strážný (N 48 $54.106^{\prime}, \mathrm{E} 13^{\circ} 43.221^{\prime}$ ) and Hliniště, an intersection of the I/4 and II/39 (N 48 $56.0952^{\prime}$, E 13²5.996'). No plants were found between this intersection and a location south of Kortusova Hut', from where the species was already reported in 2018. Hundreds of plantains were found on both sites of the $\mathrm{I} / 4$ south of Kortusova Hut, between the village and the forest. Some plants of P. coronopus were also recorded north of Kortusova Hut ( $\mathrm{N} 49^{\circ} 1.246^{\prime}$, E $\left.13^{\circ} 46.073^{\prime}\right)$. In all new locations visited in 2021, Plantago coronopus occurred on the edges of the I/4 in open landscapes. We never found the species inside villages and in sections where the $\mathrm{I} / 4$ passes through forest. $P$. coronopus successfully colonized wider curbs with open vegetation, mixtures of sand and gravel, spots with open bare soil and drying substrates. The species avoids moister forest sections and old (i.e. un-reconstructed) areas of the I/4 with narrow curbs covered in dense vegetation.

\section{Discussion and Conclusions}

Buck's-horn plantain (Plantago coronopus), the new species of a local flora, has appeared in the Bohemian Forest during the last decade. The I/4, international road, Prague - Passau is the primary migration corridor of the species. In this paper, we described the gradual spread of this species along the I/4 from the Czech-German border to within the Czech Republic. The initial $25 \mathrm{~km}$ of the road passes through a region of high conservation value (Šumava NP and Šumava PLA). We can state that the Golden Trail is no longer a corridor for the delivery of salt to the Czech Republic, but rather, a suitable migration corridor for halophytic species. P. coronopus is one of these halophytic species and its occurrence confirms the synanthropisation of the region.

Intensification of traffic and increase in the application of deicing salt to roads after the collapse of the Iron Curtain resulted in colonization by several other halophytic species. The best documented is a pilgrim of the weeping alkali grass (Puccinellia distans), a species which was unknown in the Bohemian Forest region until 1990. The first occurrences of this species were recorded in the locality of Hliniště - the I/4 in 1995 (Hadinec and Hadincová in FLDOK - Flora Database of the Czech Republic). In 1997, a local botanist František Procházka reported this same species already "from several locations along main roads in the region" (Procházka in FLDOK). Thirty years later, Puccinellia distans is a common and often dominant species along all regional roads maintained by deicing salts. In addition, Spergularia salina, another halophytic species, was not recorded in this region before 2000. This species' first records are from 2006 and 2007 where it was found in permanent transects along several roads in the region regularly treated with deicing salt (Zýval and Chocholoušková 2006). Currently, it is a common and widespread species.

There are no differences in habitus or morphology of the previously introduced species, Puccinellia distans and Spergularia salina, growing at natural or synantropic locations. The habitus of Plantago coronopus occurring in the Bohemian Forest, however, is somewhat different. Many individuals occurring in the region are smaller and of lower vitality than plants in natural habitats along the sea cost (personal observation in several sites). However, the $P$. coronopus individuals colonising new substrates, for examples mixtures of sand and gravel used for reconstruction of the road edges, can be robust, vigorous and produce many flowering stems and seeds. The seeds ripen, overwinter and germinate successfully. P. coronopus, a species natural in moderate maritime climates, can suc- 
cessfully reproduce in the cold climate of the Bohemian Forest region.

It is likely that all these halophytic species have similar strategies. Migration vectors for their seeds are cars, more precisely the tread of their tyres, which effectively scatter the seeds along the edges of roads where abundance of other species is limited due to road maintenance (snow plowing, sand sweeping, reconstruction etc.). Puccinellia distans and Spergularia salina are very successful at producing seeds but they can as well colonize certain places by vegetative reproduction. $P$. coronopus, strictly dependent on seed reproduction, successfully colonises open bare sites along the roads maintained by deicing salt, from which salt-intolerant species have left and vegetation cover is often mechanically disturbed. The species prefers dry sites and avoids more moist forest sections of the roads with dense vegetation along road edges.

We conclude that intensification of traffic and more active maintenance of the roads including applying deicing salt during the last 30 years have affected the flora and vegetation in the Bohemian Forest. Some changes in the vegetation are still only visible near roads that are regularly treated with deicing salts (Zýval et al. 2015), but successful colonization by several halophytic species has already occurred. It is unquestionable that this increased biodiversity is not welcome in this region of high nature conservation value. We believe that regulation of the use of deicing salt in the national parks and responsible road management together with careful monitoring of ecosystems along the roads could help protect sensitive habitats and minimalize the synanthropization of the Bohemian Forest flora.

\section{Acknowledgements}

We thank the Bavarian Forest NP Authority for supporting this research on the effects of deicing salt. We also thank Eric Rosenzveig for language editing.

The research was partly supported by CZ-BY Interreg project No. 368 Silva Gabreta - Monitoring of mountain ecosystems and the Interreg V project No. 26 "Silva Gabreta - Implementation of Monitoring of Biodiversity and Water Regime". The Ministry of Education, Youth and Sports of CR within the CzeCOS program, grant number LM2018123, partly supported the paper preparation.

\section{REFERENCES}

Adler W, Oswald K, Fischer R (1994) Exkursionsflora von Österreich. Ulmer, Stuttgart.

Angold PG (1997) The impact of a road upon adjacent heathland vegetation: effects on plant species composition. J Appl Ecol 34: 409-417.

Baldwin BG, Goldman D, Keil DJ, Patterson R, Rosatti TJ, Wilken DH (2012) The Jepson Manual: Vascular Plants of California. University of California Press, Barkely.
Bässler C (2004) Das Klima im Nationalpark Bayerischer Wald Darstellung, Entwicklung und Auswirkung. Nationalparkverwaltung Bayerischer Wald, Grafenau.

Bässler C, Förster B, Moning Ch, Müller J (2009) The BIOKLIM Project: Biodiversity research between climate change and wilding in a temperate montane forest - The conceptual framework, Waldökologie, Landschaftsforschung und Naturschutz, Heft 7, pp 21-34.

Braun-Blanquet J (1951) Pflanzensoziologie. Grundzüge der Vegetationskunde. 2nd ed., Springer-Verlag, Wien.

Bueno M, Lendínez ML, Aparicio C, Cordovilla MP (2017) Germination and growth of Atriplex prostrata and Plantago coronopus: Two strategies to survive in saline habitats. Flora 227: 56-63.

Chytrý M, Danihelka J., Kaplan Z. et al. (2021) Pladias Database of the Czech Flora and Vegetation. Preslia 93: 1-87.

Chytrý M, Rafajová M (2003) Czech National Phytosociological database: basic statistics of the available vegetation-plot data. Preslia 75: 1-15.

Clapham AR, Tutin TG, Warburg EF (1962) Flora of the British Isles. 2nd ed., Cambridge University Press, Cambridge.

Dinnétz P, Jerling L (1997) Gynodioecy in Plantago maritima L.; no compensation for loss of male function. Acta Bot Neerl 46: 193-206.

Ellenberg H (1991) Indicator values of plants in Central Europe. Erich Goltze KG, Göttingen.

Elling W, Bauer E, Klemm G, Koch H (1987) Klima und Böden. Nationalparkverwaltung Bayerischer Wald, Grafenau.

Findlay S, Kelly V (2011) Emerging indirect and long-term road salt effects on ecosystems. Ann NY Acad Sci 1223: 58-68.

Flowers TJ, Troke PF, Yeo AR (1977) The mechanism of salt tolerance in halophytes. Annu Rev Plant Physiol 28: 89-121.

Hultén E, Fries M (1986) Atlas of North European vascular plants: north of the Tropic of Cancer I-III. Koeltz Scientific Books, Königstein

Kilián Z, Krkavec F (1961) Floristický obraz rumišt na Ostravs$\mathrm{ku}$ [Floristic picture of rubbles in the Ostrava district]. Př́rodovědný časopis slezský 2: 255-264.

Kočárek E (2003) Geologie a hydrologie [Geology and hydrology]. In: Anděra M, Zavřel P (eds) Šumava - příroda, historie a život [Šumava - nature, history and life], Baset, Praha, pp 117-165. (In Czech).

Koelewijn HP (2004) Rapid change in relative growth rate between the vegetative and reproductive stage of the life cycle in Plantago coronopus. New Phytol 163: 67-76.

Koelewijn HP, van Damme JMM (1995) Genetics of male sterility in gynodioecious Plantago coronopus. I. Cytoplasmic variation. Genetics 139: 1749-1758

Koelewijn HP, van Damme JMM (2005) Effects of seed size, inbreeding and maternal sex on offspring fitness in gynodioecious Plantago coronopus. J Ecol 93: 373-383.

Koyro HW (2006) Effect of salinity on growth, photosynthesis, water relations and solute composition of the potential cash crop halophyte Plantago coronopus (L.). Environ Exp Bot 56: 136-146.

Kř̌enová Z, Chocholoušková Z, Zýval V (2012) Effects of applying deicing salt to roads in protected areas: a preliminary study in the Bavarian Forest National Park. Eur J Environ Sci 2: 56-61.

Křenová Z, Kindlmann P (2015) Natura 2000 - Solution for Eastern Europe or just a good start? The Šumava National Park as a test case. Biol Conserv 186: 268-275.

Křenová Z, Kindlmann P (2018) Transboundary cooperation - the best way to share common responsibility for future. In: Suratman MN (ed) National Parks - Management and Conservation. InTechOpen, pp 35-53. 
Kř̌enová Z, Zýval V, Zýval V jun., Chocholoušková Z (2018) Increasing concentration of deicing salt in soils of the Bavarian Forest National Park. Eur J Environ Sci 8: 109-116.

Kubát K, Hrouda L, Chrtek J jun., Kirschner J, Kubát K, Štech M, Štěpánek J (eds) (2002) Klíč ke květeně České republiky [Key of the Czech flora]. Academia, Praha.

Kubů F, Zavřel P (2007) Zlatá stezka. Historický a archeologický výzkum významné středověké obchodní cesty. 2. Úsek Vimperk - státní hranice. [Golden Trail. Historical and archaeological research of an important medieval trade route. Part 2: Section Vimperk - state border] Jihočeské muzeum v Českých Budějovicích, Prachatické museum, České Budějovice, Prachatice. (In Czech).

Kubů F, Zavřel P (2015) Zlatá stezka. Historický a archeologický výzkum významné stř̌edověké obchodní cesty. 4 . Úsek státní hranice - Pasov. [Golden Trail. Historical and archaeological research of an important medieval trade route. Part 4: Section state border - Pasau] Jihočeské muzeum v Českých Budějovicích, Prachatické museum, České Budějovice, Prachatice. (In Czech).

Noack EM (1979) Witterung und Klima im Bayerischen Wald. Nationalparkverwaltung Bayerischer Wald, Grafenau.

Oberdorfer E (2001) Pflanzen soziologische Exkursionsflora. 8th ed., Ulmer, Stuttgart.

Rothmaler W (2005) Exkursionsflora von Deutschland. Gefäßpflanzen: Kritischer Band. 10th ed., Elsevier, München.

Slavík B (ed) (2000) Květena České republiky. Sv. 6. [Flora of the Czech Republic, vol. 6], Academia Praha. (In Czech).

Smekens MJ, Tienderen PH (2001) Genetic variation and plasticity of Plantago coronopus under saline conditions. Acta Oecol 22: 187-200.
Štech M, Chán V, Skalický V, Žíla V (eds) (2005) Výsledky floristického kurzu ČSBS v Táboře 1988 (2.-9. 7. 1988) [Results of floristic course of the CBS in Tabor 1988 (2.-9. 7. 1988). Zprávy České botanické společnosti 40, suppl. 2005/2: 3-70. (In Czech).

Villellas J, Ehrlén J, Olesen JM, Braza R, García MB (2013) Plant performance in central and northern peripheral populations of the widespread Plantago coronopus. Ecography 36: 136-145.

Waite S (1984) Changes in the demography of Plantago coronopus at two coastal sites. J Appl Ecol 72: 809-826.

Waite S, Hutchings MJ (1978) The Effects of sowing density, salinity and substrate upon the germination of seeds of Plantago coronopus L. New Phytol 81: 341-348.

Wrobel M, Tomaszewicz T, Chudecka J (2006) Floristic diversity and spatial distribution of roadside halophytes along forest and field roads in Szczecin lowland (West Poland). Pol J Ecol 54: 303-309.

Zýval V, Chocholoušková Z (2006) Monitoring kontaktních ploch podél komunikací I. tř. v NP a CHKO Šumava [Monitoring of environmental conditions along class I roads in the Šumava NP and PLA]. Ms., project report, GeoVision Plzeň, (deposited in the GeoVision Plzeñ). (In Czech).

Zýval V, Křenová Z, Chocholoušková Z, Zýval V jun., Zývalová $\mathrm{J}$ (2015) Effects of applying deicing salt to roads in protected areas of the Bohemian Forest region. Silva Gabreta 21: 43-52.

Zýval V, Křenová Z, Raus M, Štrupl V, Zýval V jun., Zývalová J (2018) Effects of deicing salt in protected areas: Water quality monitoring in the river basin with the occurrence of a rare pearl mussel. Inz Miner 19: 99-102. 